\title{
Identification of the Outer Membrane Proteins of Campylobacter pyloridis and Antigenic Cross-reactivity between $C$. pyloridis and $C$. jejuni
}

\author{
By D. G. NEWELL \\ Experimental Pathology Laboratory, PHLS Centre for Applied Microbiology and Research, \\ Porton Down, Salisbury SP4 OJG, UK
}

(Received 1 May 1986; revised 31 July 1986)

\begin{abstract}
The outer membrane and surface exposed proteins of four strains of the gastric Campylobacterlike organism Campylobacter pyloridis were identified by SDS-PAGE of Sarkosyl-insoluble membranous material and ${ }^{125} \mathrm{I}$-surface-labelled whole bacteria. Although constant outer membrane proteins (molecular mass 61,54 and $31 \mathrm{kDa}$ ) were observed in these strains, several variable ${ }^{125}$ I-labelled surface proteins were detected. $C$. pyloridis does not appear to express a single surface-exposed major outer membrane protein like that of $C$. jejuni and $C$. coli. Putative flagella proteins were identified from isolated flagella and acid-extractable surface material and by immunoblotting with anti-flagella antibodies. Several major protein antigens were observed by immunoblotting with anti- $C$. pyloridis antisera. At least two of these antigens cross-reacted with anti- $C$. jejuni antiserum. This cross-reaction appears to be caused primarily by flagellar antigens. However, one major protein antigen $(61 \mathrm{kDa})$ was not cross-reactive with $C$. jejuni and may, therefore, be useful in serological tests for the specific diagnosis of $C$. pyloridis infections.
\end{abstract}

\section{INTRODUCTION}

Campylobacter pyloridis is a recently recognized microaerophilic, S-shaped bacterium (Warren \& Marshall, 1983), previously termed gastric Campylobacter-like organism type 1 (GCLO-1) which colonizes the gastric mucosa of patients with active, chronic gastritis and peptic ulceration (McNulty \& Watson, 1984; Langenberg et al., 1984; Booth et al., 1986; Jones et al., 1984). Despite this close association with abnormal gastric pathology the pathogenic, as distinct from opportunistic, nature of this organism has yet to be proven. Nevertheless, the presence of $C$. pyloridis may be an important consideration in the treatment of gastric disease.

Patients colonized with $C$. pyloridis elicit a specific antibody response (Jones et al., 1984; Kaldor et al., 1985) potentially useful as a diagnostic aid and for monitoring the disease state during treatment. Consequently ELISA systems are being developed to detect serum anti- $C$. pyloridis antibodies (Booth et al., 1986). However, preliminary studies suggest that $C$. pyloridis displays antigenic cross-reactivity with the thermophilic campylobacters $C$. jejuni and $C$. coli (Hutchinson et al., 1985; Newell, 1986 b), which could result in lack of specificity with whole cell antigens.

The aim of these investigations was to identify the outer membrane and surface proteins, including flagella, of $C$. pyloridis and to establish which of these proteins were antigenically cross-reactive with the surface antigens of $C$. jejuni.

\section{METHODS}

Bacterial strains. C. pyloridis strains NCTC 11637 and NCTC 11638 were isolated by Dr B. Marshall (Royal Perth Hospital, Perth, Australia) and kindly supplied by Dr M. B. Skirrow (Worcester Royal Infirmary, Worcester, UK). C. jejuni strain 81116 was described by Newell et al. (1984). All other strains were obtained from gastric biopsies and were isolated on blood agar (blood agar base no. 2; Oxoid) containing $5 \%$ (v/v) defibrinated horse blood and $2 \%(\mathrm{w} / \mathrm{v})$ agar with or without Skirrow's antibiotics (Skirrow, 1977) in microaerophilic conditions and stored in $10 \%(\mathrm{w} / \mathrm{v})$ glycerol in $1 \%(\mathrm{w} / \mathrm{v})$ proteose peptone in liquid nitrogen. 
Antisera and antibodies. Rabbit antisera were prepared against C. pyloridis strain 11637, C. jejuni strain 81116 and $C$. jejuni flagella (Newell et al., 1984). The production and characterization of the monoclonal antibody CF5 was described by Newell $(1986 a, b)$.

Outer membrane preparation. Outer membranes of $C$. pyloridis strains NCTC 11637, NCTC 11638, 85033 and 85034 were prepared by solubilization of crude membrane preparations with sodium $N$-lauroyl sarcosinate (Newell et al., 1984).

Acid extraction. Acid extracts of whole organisms were prepared from strains NCTC 11637, NCTC 11638 and 85033 by incubation in $0.2 \mathrm{M}$-glycine/ $\mathrm{HCl}$ buffer, pH 2.2 (Newell et al., 1984).

Flagella preparation. $C$. pyloridis strain 85033 was cultured in a broth containing $1 \%(\mathrm{w} / \mathrm{v})$ peptone, $1 \%(\mathrm{w} / \mathrm{v})$ tryptose, $0 \cdot 1 \%(\mathrm{w} / \mathrm{v})$ dextrose, $0.2 \%(\mathrm{w} / \mathrm{v})$ yeast extract (all from Oxoid), $0 \cdot 5 \%(\mathrm{w} / \mathrm{v})$ sodium chloride, $0 \cdot 01 \%(\mathrm{w} / \mathrm{v})$ sodium metabisulphite, $10 \%(\mathrm{v} / \mathrm{v})$ horse blood lysate and Skirrow's antibiotics at $37{ }^{\circ} \mathrm{C}$ in microaerophilic conditions and rotated on an orbital shaker at 80 r.p.m. Flagella were sheared from the bacteria and purified by differential centrifugation (Newell et al., 1984). The preparation was monitored by negative staining and transmission electron microscopy, and by SDS-PAGE.

${ }^{125}$ I-surface-labelling of whole bacteria. C. pyloridis strains were harvested from blood agar plates and washed twice by centrifugation $\left(5000 \mathrm{~g}, 10 \mathrm{~min}, 4^{\circ} \mathrm{C}\right)$ in phosphate-buffered saline (PBS: $140 \mathrm{~mm}$-sodium chloride, $2.7 \mathrm{~mm}$-potassium chloride, $8 \mathrm{~mm}$-disodium hydrogen phosphate and $1.5 \mathrm{~mm}$-potassium dihydrogen phosphate, pH 7-2). Bacteria were ${ }^{125}$ I-surface-labelled using 1,3,4,6-tetrachloro- $3 \alpha$ - $6 \alpha$-diphenyl-glycouril (Iodogen) as described by Newell et al. (1984). The specific activity of ${ }^{125} \mathrm{I}$-labelled bacteria was approximately $1 \mu \mathrm{Ci}(\mu \mathrm{g}$ protein $)^{-1}\left[37 \mathrm{kBq}(\mu \mathrm{g} \text { protein })^{-1}\right]$.

SDS-PAGE. A $10-25 \%(\mathrm{w} / \mathrm{v})$ linear gradient SDS-PAGE system was used (Lambden et al., 1979). Protein bands were stained with Kenacid blue (BDH). The protein molecular mass markers (Sigma) were $\alpha$-lactalbumin, trypsin inhibitor, trypsinogen, carbonic anhydrase, glyceraldehyde-3-phosphate dehydrogenase, egg albumin and bovine albumin.

Electroimmunoblotting. SDS-PAGE gels of the total proteins, outer membrane preparations, acid extracts and flagella preparations were electroblotted onto Hybond paper (Amersham) at $55 \mathrm{~V}$ for $18 \mathrm{~h}$ at $4{ }^{\circ} \mathrm{C}$ in $24 \mathrm{~mm}$-Tris, $190 \mathrm{~mm}$-glycine and $20 \%(\mathrm{v} / \mathrm{v})$ methanol, $\mathrm{pH} 8.0$. Non-specific binding was blocked by incubation with $3 \%(\mathrm{w} / \mathrm{v})$ gelatin in $10 \mathrm{~mm}$-Tris $/ \mathrm{HCl}, 150 \mathrm{~mm}$-sodium chloride containing $0.05 \%(\mathrm{v} / \mathrm{v})$ Tween 20 (TTBS), pH 7.4, for $2 \mathrm{~h}$ at $20^{\circ} \mathrm{C}$. The blots were incubated in rabbit antiserum ( 1 in 100) diluted in $50 \mathrm{~mm}$-Tris/ $\mathrm{HCl}$ buffer, $\mathrm{pH} \mathrm{7.4,}$ containing 150 mM-sodium chloride, $5 \mathrm{~mm}$-EDTA, $0.25 \%(\mathrm{w} / \mathrm{v})$ gelatin and $0.05 \%(\mathrm{v} / \mathrm{v})$ Nonidet P-40 (incubation buffer) or in undiluted hybridoma supernatant fluid containing $20 \mathrm{~mm}$-HEPES (pH 7.4) for $2 \mathrm{~h}$ at $20^{\circ} \mathrm{C}$. After washing in TTBS the blots were incubated in goat anti-rabbit IgG (diluted 1 in 3000 in incubation buffer) (BioRad) for $1 \mathrm{~h}$ at $20^{\circ} \mathrm{C}$ or in ${ }^{125} \mathrm{I}$-labelled sheep anti-mouse $\mathrm{IgG}$ (diluted to $1 \times 10^{6} \mathrm{c} . \mathrm{p} . \mathrm{m}$. $\mathrm{ml}^{-1}$ ) in incubation buffer) [Amersham; specific activity $5-20 \mu \mathrm{Ci} \mu \mathrm{g}^{-1}\left(185-740 \mathrm{kBq} \mu \mathrm{g}^{-1}\right)$ ] overnight at $4{ }^{\circ} \mathrm{C}$. The unbound material was removed by extensive washing in TTBS. Bound peroxidase activity was detected using 4-chloro-1-naphthol and hydrogen peroxide. Bound ${ }^{125} \mathrm{I}$-labelled material was detected by autoradiography.

ELISA. Antigen $\left.\left[10 \mu \mathrm{g} \text { protein }(\mathrm{ml} \text { whole cell sonicate) })^{-1} \text { or } 5 \mu \mathrm{g} \text { protein (ml acid extract) }\right)^{-1}\right]$ in $100 \mu 10 \cdot 1 \mathrm{M}$ potassium carbonate buffer, $\mathrm{pH} 9.6$, was adsorbed onto microELISA plates (Dynatech) overnight at $20^{\circ} \mathrm{C}$. The wells were washed in ELISA wash (145 mm-sodium chloride containing $0.05 \%, \mathrm{v} / \mathrm{v}$, Tween 20 ) and incubated with appropriate dilutions of rabbit antisera for $2 \mathrm{~h}$ at $37^{\circ} \mathrm{C}$. After washing, the wells were incubated with $100 \mu \mathrm{lgoat}$ anti-rabbit IgG coupled to peroxidase (Miles Research Labs) (1 in 1000 dilution in ELISA wash containing $1 \%$, $\mathrm{w} / \mathrm{v}$, bovine serum albumin and $5 \mathrm{~mm}$-Tris/ $\mathrm{HCl}, \mathrm{pH} \mathrm{7.6)}$ for $2 \mathrm{~h}$ at $37^{\circ} \mathrm{C}$. Bound antibody was detected with $100 \mu \mathrm{l}$ tetramethylbenzidine substrate for $15 \mathrm{~min}$, stopped with $50 \mu \mathrm{l} 1 \mathrm{M}$-sulphuric acid and read at $450 \mathrm{~nm}$ in a microELISA reader (Dynatech). The ELISA titres were calculated as described by Virji et al. (1983).

\section{RESULTS}

\section{Outer membrane and surface proteins}

The total protein profiles of the four strains of $C$. pyloridis were very similar but no significant major protein bands were observed. SDS-PAGE gels of the total protein profile, crude membrane preparation, Sarkosyl-soluble material and Sarkosyl-insoluble membranous material from strain 85033 are shown in Fig. $1 a$. Three outer membrane proteins $(61,54$ and $31 \mathrm{kDa})$ were seen in this strain. The protein profiles of outer membrane preparations from the other strains showed proteins bands of the same molecular mass though some quantitative differences were observed. The outer membrane preparation, when viewed by transmission electron microscopy, contained membranous material and many 'doughnut-shaped' $11 \mathrm{~nm}$ particles. Flagella fragments were rarely seen (Fig. $2 a$ ). 
(a)

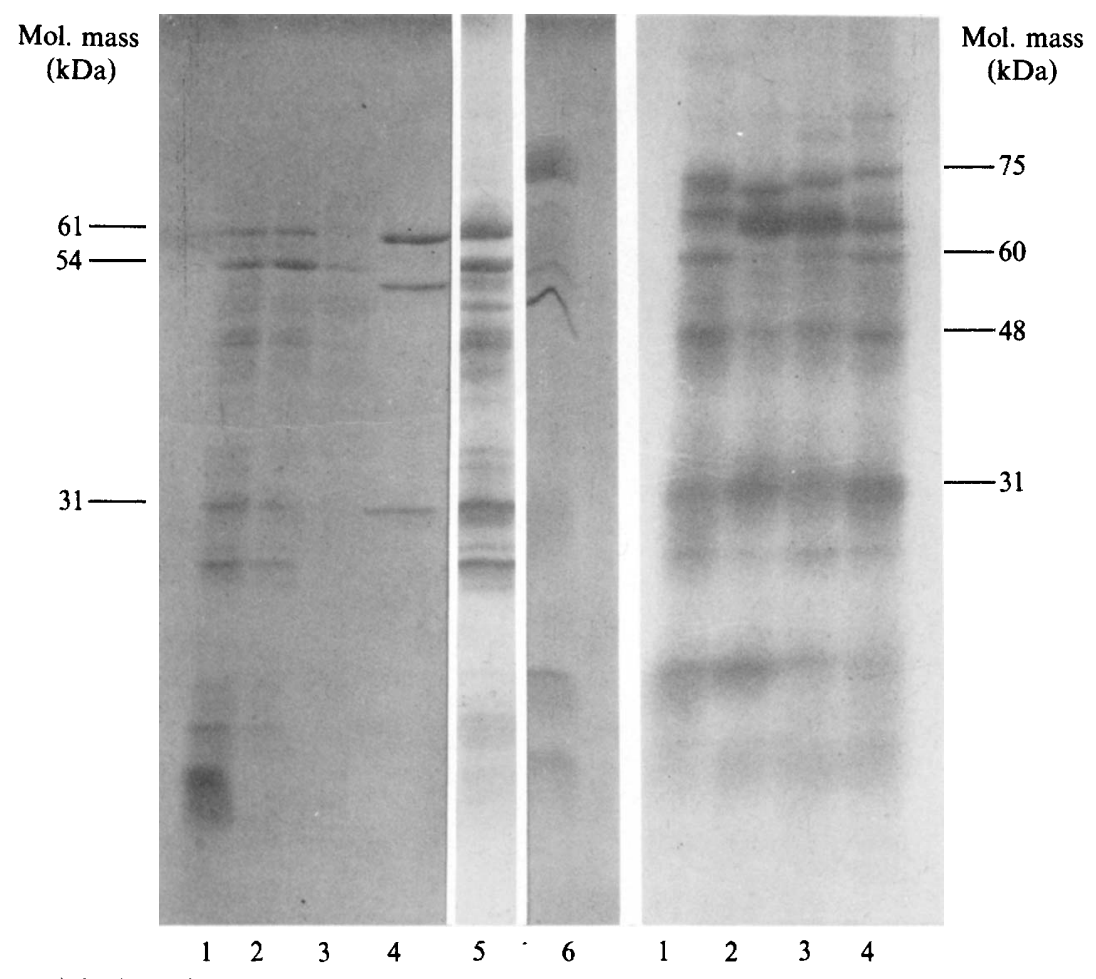

Fig. 1. (a) SDS-PAGE gel of $C$. pyloridis strain 85033 . Track 1, total protein profile; track 2, crude membrane preparation; track 3, Sarkosyl-soluble membranous material; track 4, Sarkosyl-insoluble outer membrane; track 5, acid extract; and track 6, flagella preparation. All preparations were loaded at $10 \mu \mathrm{g}$ protein per track and the gel was stained with Kenacid blue. (b) Autoradiograph of SDS-PAGE gel of ${ }^{125} \mathrm{I}$-surface-labelled $C$. pyloridis strains. Track 1, strain 11637; track 2, strain 11638; track 3, strain 85033; and track 4, strain 85034.

The 61 and $54 \mathrm{kDa}$ proteins, and a $73 \mathrm{kDa}$ major protein, were also present in the flagella preparation (Fig. $1 a$, track 6). An additional $40-50 \mathrm{kDa}$ protein always ran as a distorted band in this preparation. Untreated organisms expressed multiple flagella many of which were sheathed and had terminal 'paddles', which appeared to be extensions of the flagella sheath. Most flagella fragments recovered after shearing were characterized by amorphous terminal blebs at both ends (Fig. $2 c$ ). This amorphous material represented a large proportion of the final flagella preparation. Conversely the 'doughnut-shaped' particles seen in the outer membranes were infrequently observed in this preparation.

Acid-extracted whole bacteria were without flagella but otherwise appeared intact. Acid extracts from all strains had similar protein profiles and had four major $(61,56,31$ and $25 \mathrm{kDa})$ proteins (Fig. $1 a$, track 5).

${ }^{125}$ I-surface-labelled bacteria (Fig. $1 b$ ) demonstrated several variable proteins, including a $71.5-75 \mathrm{kDa}$ protein and a $48-50 \mathrm{kDa}$ protein. A 65.5 and $64.5 \mathrm{kDa}$ doublet band was seen in strains 85033 and 11638 ; the high molecular mass band only was seen in strain 85034 whilst the lower molecular mass band only was seen in strain 11637 . Several ${ }^{125}$ I-labelled major proteins $(60,31,26$ and $19 \mathrm{kDa})$ were also observed, which had the same molecular mass in each strain.

\section{Surface antigens of $C$. pyloridis}

Rabbit anti- $C$. pyloridis antiserum labelled five major antigens (61, 56, 54, 29 and $26 \mathrm{kDa})$ in all four strains of $C$. pyloridis (Fig. $3 a$ ). Several variable antigens were also observed, including a $26 \mathrm{kDa}$ antigen which was missing in strain 11674 . The $61 \mathrm{kDa}$ antigen was a major antigenic 

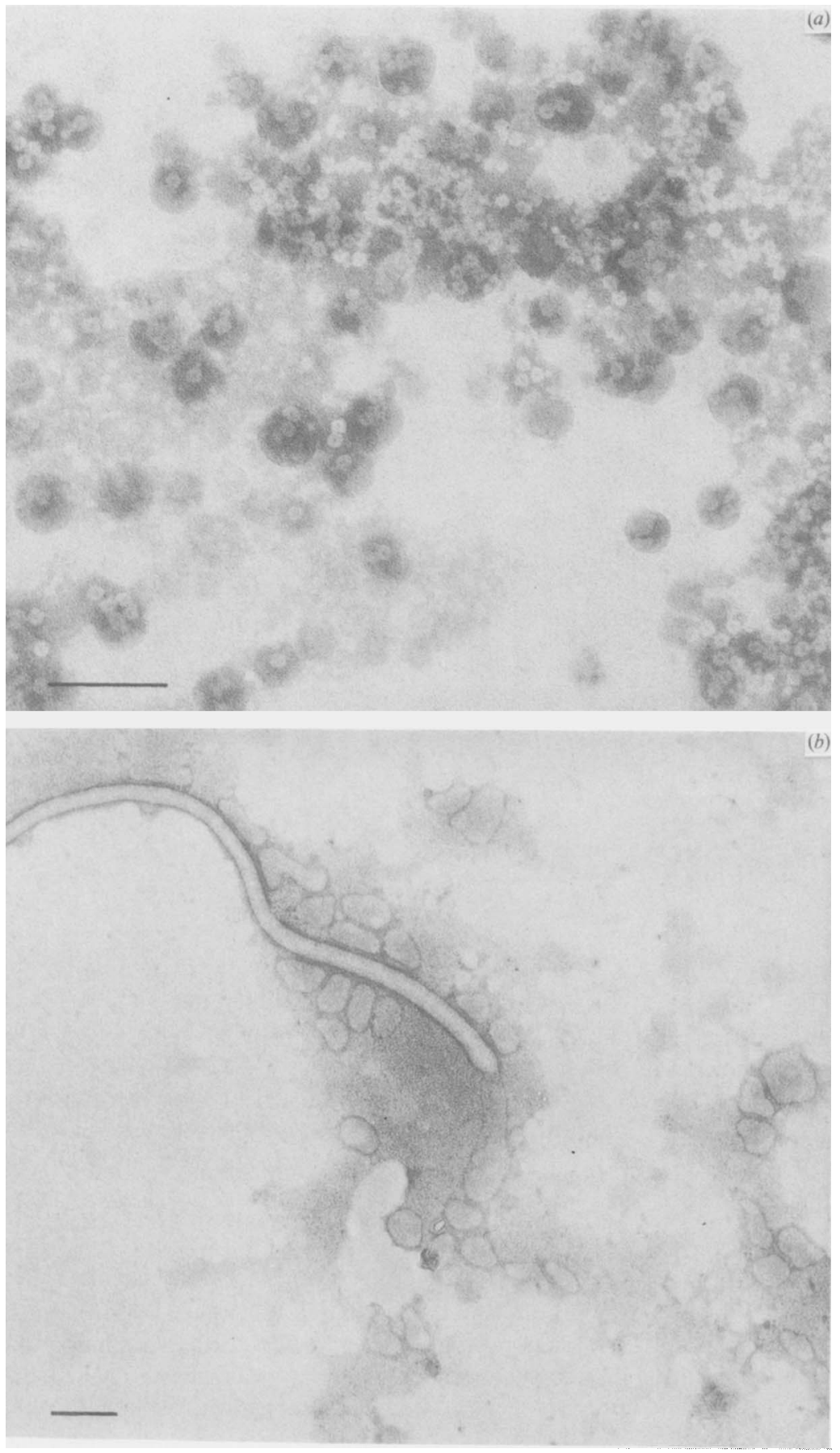

Fig. 2. Transmission electron micrograph of negatively stained (a) outer membrane material showing $11 \mathrm{~nm}$ 'doughnut-shaped' particles (bar $0.1 \mu \mathrm{m}$ ), and (b) flagella fragment after mechanical dissociation showing the dispersion of amorphous material from one end (bar $0.1 \mu \mathrm{m}$ ). 
(a)

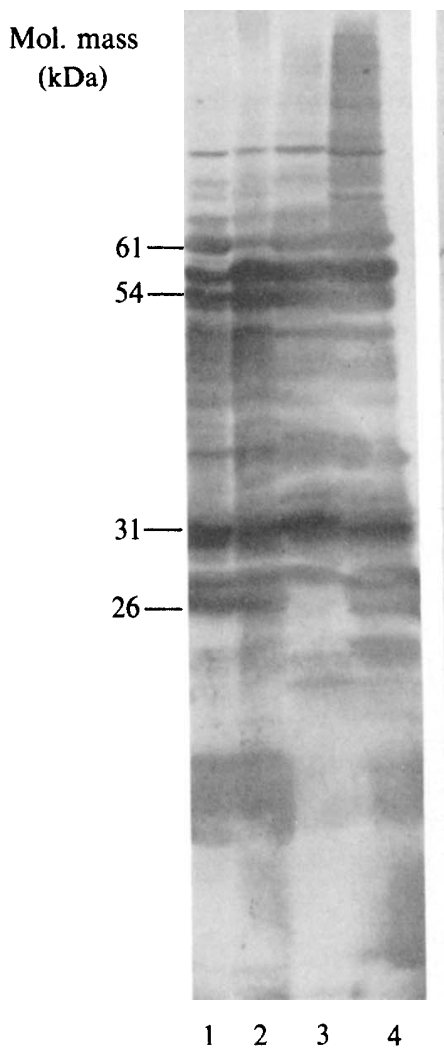

(b)

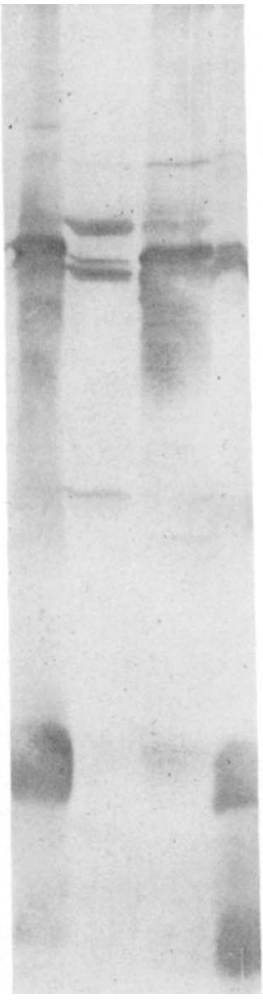

(c)

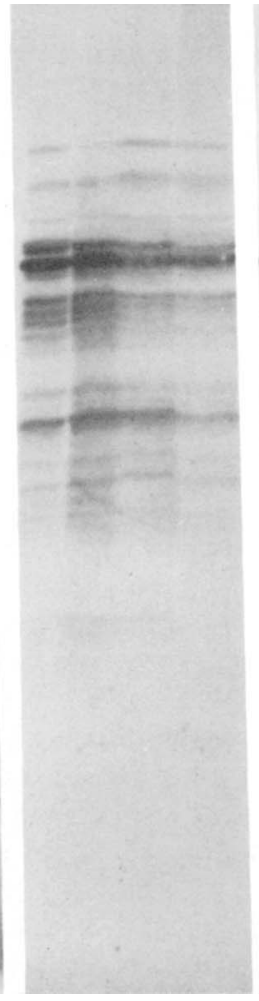

$(d)$

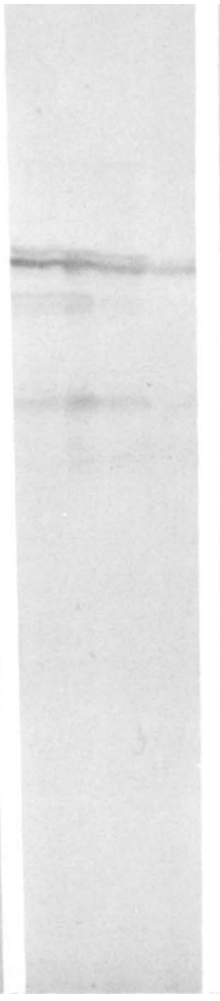

(e)

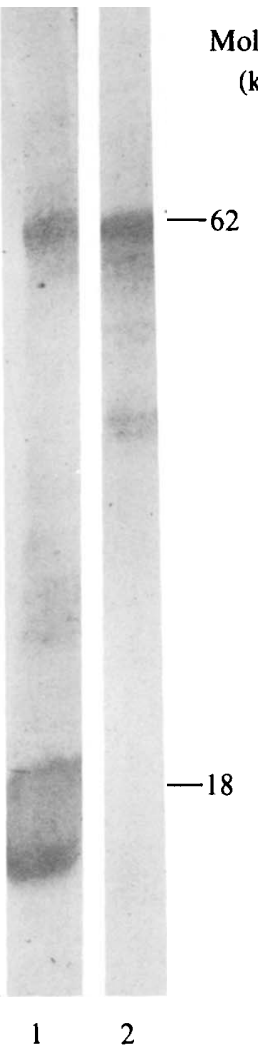

Mol. mass

(kDa)

Fig. 3. Electroimmunoblots of SDS-PAGE gels of the following: (a) total protein profiles of C.pyloridis strain 11637 (track 1), strain 11638 (track 2), strain 85033 (track 3) and strain 85034 (track 4), all incubated with rabbit anti- $C$. pyloridis antiserum. (b) Total protein profile (track 1), outer membrane preparation (track 2), acid extract (track 3) and flagella preparation (track 4) of strain 85033, all incubated with rabbit anti- $C$. pyloridis antiserum. $(c)$ As $(a)$ but incubated with rabbit anti- $C$. jejuni antiserum. $(d)$ As $(a)$ but incubated with rabbit anti- $C$. jejuni flagella antiserum. (e) Total protein profile of $C$. jejuni strain 81116 incubated with rabbit anti- $C$. pyloridis antiserum (track 1) and rabbit anti- $C$. jejuni antiserum (track 2).

component of the outer membrane preparation, while the $56 \mathrm{kDa}$ antigen was a major constituent of the acid extract and flagella preparations. The immunolabelling pattern of this $56 \mathrm{kDa}$ protein indicated that several antigens of similar molecular masses might be present. The $54 \mathrm{kDa}$ antigen was found in the outer membrane and flagella preparations (Fig. $3 b$ ).

\section{Cross-reacting surface antigens of $C$. pyloridis and C. jejuni}

Both C. jejuni and C.pyloridis sonicated whole cell antigen preparations cross-reacted with the heterologous antisera in ELISA (Table 1). However, the cross-reactivity was greatly reduced when acid extracts of $C$. pyloridis were used. By immunoblotting it could be seen that the major antigens of $C$. pyloridis cross-reacting with rabbit anti- $C$. jejuni were 56 and $54 \mathrm{kDa}$ proteins (Fig. $3 c$ ). Rabbit anti-C. jejuni flagella antiserum (Fig. $3 d$ ) and the monoclonal antibody CF5 labelled the same antigens.

Rabbit anti-C.pyloridis antisera labelled a $62 \mathrm{kDa}$ and a diffuse $18 \mathrm{kDa}$ band in blots of whole cell protein profiles of $C$. jejuni 81116 (Fig. $3 e$ ). The $62 \mathrm{kDa}$ antigen was also labelled in acid extracts of 81116 and was the major antigen labelled by the homologous antisera. The $18 \mathrm{kDa}$ diffuse band was not detected by anti-C. jejuni antisera. 
Table 1. Antigenic cross-reactivity between C. pyloridis and C. jejuni

Antisera from rabbits, immunized with either $C$. pyloridis or $C$. jejuni, were reacted in ELISA with either whole cell sonicates or acid-extractable material from $C$. pyloridis or $C$. jejuni. The titre was calculated as the dilution of sera which gave an increase in $A_{450}$ of $0 \cdot 1$ after 15 min incubation with the substrate.

\author{
Antigen \\ C. pyloridis strain 11637 \\ C. jejuni strain 81116
}

Whole-cell sonicate Acid extract

Whole-cell sonicate Acid extract
$10^{1} \times$ ELISA titre

$\begin{array}{ccc}\begin{array}{c}\text { Anti-C. pyloridis } \\ \text { strain } 11637\end{array} & \begin{array}{c}\text { Anti-C. jejuni } \\ \text { strain } 81116\end{array} & \begin{array}{c}\text { Norma } \\ \text { rabbit } \\ \text { serum }\end{array} \\ 1782 & 111 & 0 \\ 111 & 2 & 0 \\ 74 & 1024 & 0 \\ 60 & 270 & 0\end{array}$

\section{DISCUSSION}

The outer membrane and surface exposed proteins of $C$. pyloridis have been identified by ${ }^{125} \mathrm{I}-$ surface-labelling and SDS-PAGE of outer membrane material. These techniques have been previously used to identify the outer membrane and surface proteins of other members of the genus Campylobacter (Logan \& Trust, 1982; Blaser et al., 1983; Newell et al., 1984). The total protein profiles of the $C$. pyloridis strains were similar to those described by Megraud et al. (1985). No major outer membrane protein was observed in C. pyloridis. Similarly no major surface protein was ${ }^{125} \mathrm{I}$-labelled. Many of the surface exposed proteins that were ${ }^{125} \mathrm{I}$-labelled appear to be peripheral proteins rather than constituents of the outer membrane. Nevertheless the 61 and $31 \mathrm{kDa}$ outer membrane proteins appear to be surface exposed. The thermophilic campylobacters $C$. jejuni and $C$. coli are characterized by a single, $42-47 \mathrm{kDa}$, surface-exposed outer membrane protein whilst $C$. fetus contains two distinctive outer membrane proteins (Logan \& Trust, 1982; Blaser et al., 1983; Newell et al., 1984). It appears that $C$. pyloridis does not possess a major outer membrane protein comparable with those of other campylobacters. The inclusion of GCLO-1 in the genus Campylobacter (Anon., 1985) has been questioned (Jones et al., 1985; Goodwin et al., 1985, 1986) on the basis of significant differences in morphology, fatty acids and antibiotic susceptibility. However, other properties of the organism (Wait \& Hudson, 1985; Marshall et al., 1984; Megraud et al., 1985) are consistent with the definition of Campylobacter (Smibert, 1978).

In previous studies, the $62 \mathrm{kDa}$ flagella protein of $C$. jejuni has been identified after mechanical isolation of flagella. Moreover, this protein was a major component of both outer membrane preparations and acid-extractable surface material. The use of similar techniques did not allow unequivocal identification of the flagella proteins of $C$. pyloridis, the flagella preparation of which gave a complex protein profile, including one protein which appeared to be disturbed during electrophoresis. Such a perturbation may result from changes in ionic strength within the gel, though such effects were not seen with other preparations or from association with non-proteinaceous materials like membrane lipids. The amorphous material, representing much of the flagella preparation, appeared to originate from the terminal blebs of sheathed flagella. Conversely the flagella of the thermophilic campylobacters which remain intact during mechanical dissociation from the cells and fragments of flagella are major components of the outer membrane material from these Campylobacter spp. (Newell et al., 1984). Morphological studies by Goodwin et al. (1985) suggest that the flagella sheath of $C$. pyloridis is an extension of the outer membrane. The protein profiles of the outer membrane and flagella preparations are not inconsistent with this proposal but the 'doughnut-like' particles, associated with the cell surface (Jones et al., 1985), were infrequent in the flagella preparations. Obviously the flagella of C. pyloridis are both morphologically (Jones et al., 1985; Goodwin et al., 1985 ) and chemically distinct from those of the other campylobacters. Nevertheless, there is considerable antigenic cross-reactivity between the flagella of Campylobacter spp. Anti-C. jejuni flagella antiserum immunolabelled at least two proteins found in the flagella preparation and acid extract of $C$. pyloridis. Moreover, the monoclonal antibody CF5, which is directed against 
the $62 \mathrm{kDa}$ flagella protein of $C$. jejuni (Newell, 1986a) and which cross-reacts with most Campylobacter species (Newell, 1986 b) also labels these proteins.

The $61 \mathrm{kDa}$ protein was one of the major $C$. pyloridis antigens detected by rabbit anti- $C$. pyloridis antisera which did not cross-react with anti- $C$. jejuni antiserum. Preliminary evidence suggests that a $60-62 \mathrm{kDa}$ protein is a major antigen detectable by electroimmunoblotting and radioimmunoprecipitation using sera from patients colonized by $C$. pyloridis (Newell, 1985). This $61 \mathrm{kDa}$ protein is therefore a candidate antigen for enhancing the specificity and sensitivity of ELISA techniques. The $61 \mathrm{kDa}$ protein is enriched in the acid-extractable material from $C$. pyloridis and has a significantly lower cross-reactivity with rabbit anti-C. jejuni antiserum than with whole cell sonicates. Further ELISA investigations using the acidextractable material for the detection of specific anti-C. pyloridis antibody responses in patients with gastritis are in progress.

I would like to thank Mr H. Steer (Department of Surgery, Southampton) for providing the gastric biopsies and Mr P. Hawtin (PHLS, Southampton) for isolating the bacteria.

\section{REFERENCES}

ANON. (1985). International Journal of Systematic Bacteriology list 17. International Journal of Systematic Bacteriology 35, 223-225.

Blaser, M. J., Hopkins, J. A., Berka, R. M., Vasil, M. L. \& WANG, W. L. L. (1983). Identification and characterization of Campylobacter jejuni outer membrane proteins. Infection and Immunity 42, 276-284.

Booth, L., Holdstock, G., MacBride, H., Hawtin, P., Gibson, J. R., Ireland, A., Bamforth, J., Duboulay, C. E., Lloyd, R. S. \& Pearson. A. D. (1986). Clinical importance of Campylobacter pyloridis and associated $\operatorname{IgG}$ and $\operatorname{IgA}$ antibody responses in patients undergoing upper gastrointestinal endoscopy. Journal of Clinical Pathology 39, 215-219.

Goodwin, C. S., McCulloch, R. K., Armstrong, J. A. \& WEE, S. H. (1985). Unusual cellular fatty acids and distinctive ultrastructure in a new spiral bacterium (Campylobacter pyloridis) from the human gastric mucosa. Journal of Medical Microbiology 19, 257-267.

Goodwin, C. S., Blake, P. \& Blincow, E. (1986). The minimum inhibitory and bacteriocidal concentrations of antibiotics and anti-ulcer agents against Campylobacter pyloridis. Journal of Antimicrobial Chemotherapy 17, 309-314.

Hutchinson, D. N., Bolton, F. J., Hinchliffe, P. M. \& HolT, A. V. (1985). Distribution in various clinical groups of antibody to Campylobacter pyloridis detected by ELISA, complement fixation and microagglutination tests. In Campylobacter III, p. 185. Edited by A. D. Pearson, M. B. Skirrow, H. Lior \& B. Rowe. London: PHLS.

Jones, D. M., Lessells, A. M. \& EldRIDGe, J. (1984). Campylobacter-like organism on the gastric mucosa: culture, histological and serological studies. Journal of Clinical Pathology 37, 1002-1006.

Jones, D. M., Curry, A. \& Fox, A. J. (1985). An ultrastructural study of the gastric Campylobacterlike organism 'Campylobacter pyloridis'. Journal of General Microbiology 131, 2335-2341.

Kaldor, J., Tee, W., McCarthy, P., Watson, J. \& DWYER, B. (1985). Immune response to Campylo- bacter pyloridis in patients with peptic ulceration. Lancet i, 921.

LAMBden, P. R., HeCkels, J. E., JAMES, L. T. \& WATtS, P. J. (1979). Variations in surface protein composition associated with virulence properties in opacity types of Neisseria gonorrhoeae. Journal of General Microbiology 114, 305-312.

Langenberg, M. L., Tytgat, G. N., Schipper, M. E. I., Rietra, P. J. G. M. \& Zanen, H. C. (1984). Campylobacter-like organisms in the stomach of patients and healthy individuals. Lancet i, 1348.

LoGAN, S. M. \& TRUST, T. J. (1982). Outer membrane characteristics of Campylobacter jejuni. Infection and Immunity 38, 898-906.

McNulty, C. A. M. \& Watson, D. M. (1984). Spiral bacteria of the gastric antrum. Lancet i, 1068-1069.

Marshall, B. J., Royce, H., Annear, D. I., Goodwin, C. S., Pearman, J. W., Warren, J. R. \& ARMSTRONG, J. A. (1984). Original isolation of Campylobacter pyloridis from human gastric mucosa. Microbios 25, 83-88.

Megraud, F., Bonnet, F., Garnier, M. \& LAmouliatTe, H. (1985). Characterisation of 'Campylobacter pyloridis' by culture, enzymatic profile and protein content. Journal of Clinical Microbiology 22, 1007-1010.

Newell, D. G. (1985). The outer membrane proteins and surface antigens of Campylobacter pyloridis. In Campylobacter III, pp. 199-200. Edited by A. D. Pearson, M. B. Skirrow, H. Lior \& B. Rowe. London: PHLS.

NewELL, D. G. (1986a). Monoclonal antibodies directed against the flagella of Campylobacter jejuni: production, characterization and lack of effect on the colonization of infant mice. Journal of Hygiene 96, 131-141.

Newell, D. G. (1986b). Monoclonal antibodies directed against the flagella of Campylobacter jejuni: cross-reacting and serotypic specificity and potential use in diagnosis. Journal of Hygiene 96, 377-384.

Newell, D. G., McBride, H. \& Pearson, A. D. (1984). The identification of outer membrane proteins and flagella of Campylobacter jejuni. Journal of General Microbiology 130, 1201-1208. 
SkIRROW, M. B. (1977). Campylobacter enteritis: a 'new' disease. British Medical Journal 2, 9-11.

SmiberT, R. M. (1978). The genus Campylobacter. Annual Review of Microbiology 32, 673-709.

VIRJI, M., Heckels, J. E. \& WaTt, P. J. (1983). Monoclonal antibodies to gonococcal pili : studies on antigenic determinants on pili from variants of strain P9. Journal of General Microbiology 129, 27612768.
WaIT, R. \& Hudson, M. J. (1985). The use of picolinyl esters for the characterization of microbial lipids: application to the unsaturated and cyclopropane fatty acids of Campylobacter species. Letters in Applied Microbiology 1, 95-99.

WarRen, J. R. \& MARShall, B. (1983). Unidentified curved bacilli on the gastric epithelium in active chronic gastritis. Lancet i, 1273-1275. 